\title{
UNIVERSITY OF GRANADA RADIOCARBON DATES VII
}

\section{CECILIO GONZÁLEZ-GÓMEZ}

Consejo Superior de Investigaciones Científicas and Departamento de Química Inorgánica, Radioquímica, Facultad de Ciencias, Universidad de Granada, E-18071 Granada, Spain

and

\section{ELENA VILLAFRANCA-SÁNCHEZ}

Centro de Instrumentación Científica, Servicios Técnicos de Apoyo a la Investigación, Universidad de Granada, E-18071 Granada, Spain

\section{INTRODUCTION}

This paper includes determinations of archaeological, geological and palaeobotanical samples from Spain and Portugal, measured at the University of Granada Radiocarbon Dating Laboratory, from 1990 to 1991. Pretreatment of charcoal and wood samples is a standard acid-basic procedure using $8 \% \mathrm{HCl}$ and $2 \% \mathrm{NaOH}$ at boiling temperature. The collagen of bone samples is obtained by the Longin (1971) method. The method of dating is benzene synthesis and liquid scintillation counting.

As previously reported (González-Gómez 1992), the sample size and the scintillator were $7 \mathrm{ml}$ low K-40 Packard counting picovials with $5 \mathrm{ml}$ synthesized benzene and $83.5 \mathrm{mg}$ Butyl-PBD directly dissolved in the benzene ( $16.7 \mathrm{~g} /$ liter) as a scintillator; smaller samples were expanded to $5 \mathrm{ml}$ with inactive benzene. ${ }^{14} \mathrm{C}$ activity was measured in a Packard Tri-Carb ${ }^{\circledR}$ Mod 4640 liquid scintillation spectrometer. Efficiency was $\sim 65 \%$ using the part of the spectrum above the end point of tritium, with a background of $\sim 7 \mathrm{cpm}$. At least one modern reference standard and two background vials were measured together with each series of measurements. All results are corrected for fractionation according to the quoted $\delta^{13} \mathrm{C}$ (w.r.t. PDB) values.

In order to prevent any loss of benzene during counting and storage, we sealed the vials hermetically using metallic caps. The joint was made of a sheet composed of $3 \mathrm{~mm}$ silicone $+0.05 \mathrm{~mm}$ Teflon ${ }^{\mathrm{TM}}$. As a second barrier we placed a silicone O-ring, $10 \mathrm{~mm}$ in inner diameter and $2 \mathrm{~mm}$ thick, around the neck of the vial. The weight of vials, checked one year after filling, remained constant (González-Gómez 1992).

Dates reported here are based on 0.95 of the activity of NBS oxalic acid modern standard, on the Libby ${ }^{14} \mathrm{C}$ half-life of $5568 \mathrm{yr}$, and are expressed in radiocarbon years relative to $\mathrm{AD} 1950$, as suggested by Stuiver and Polach (1977). Samples were measured for 100 min repeated $40-45$ times, as well as background and standard vials. The standard deviation quoted includes only $1 \sigma$ of the counting statistics of background, sample and modern standard counts. Calculations and data were processed using a PC running a general program for radiocarbon dating laboratories written by González-Gómez (1995). Calibrated ages for a $2 \sigma$ interval were obtained by the method of Pearson et al. (1986), running the computer programs CALIB (Stuiver and Reimer 1986) and CALI (González-Gómez 1988) and using the bidecadal curve for samples of atmospheric origin. Sample descriptions and comments are essentially based on information provided by submitters.

\section{ACKNOWLEDGMENT}

We thank the Departamento de Química Analítica, Facultad de Química, Universidad de Barcelona, for the $\delta^{13} \mathrm{C}$ determinations. 


\section{ARCHAEOLOGICAL SAMPLES}

SPAIN

\section{Acinipo. Ronda La Vieja Series}

Charcoal samples from Acinipo, Ronda la Vieja $\left(36^{\circ} 45^{\prime} \mathrm{N}, 5^{\circ} 10^{\prime} \mathrm{W}\right)$, Ronda, Málaga province, were collected from 1986 to 1988 by O. Garrido and M. Carrilero and submitted in 1990 by P. Aguayo, Departamento de Prehistoria y Arqueología, Universidad de Granada, to date the Bronze Age and particularly the building systems of the habitats in the site.

UGRA-360. Ac'88 - 41568

Charcoal from depth $6.92 \mathrm{~m}$; 2350-1930 cal BC.

$3720 \pm 70$

UGRA-374. Ac'86 - 40710

Charcoal from depth $6.87 \mathrm{~m}$; 2200-1786 cal BC. $\delta^{13} C=-26.2 \%$

UGRA-375. Ac' 86 - 40718

Charcoal from depth $6.40 \mathrm{~m} ; 2180-1890 \mathrm{cal}$ BC.

$3640 \pm 70$

$\delta^{13} C=-24.8 \%$

$3640 \pm 50$

$\delta^{13} C=-24.5 \%$

General Comment: Expected ages were $\sim 3710 \pm 250$ BP.

\section{Cerro De Los Encaños Series}

Charcoal samples from Cerro de los Encaños $\left(40^{\circ} 03^{\prime} \mathrm{N}, 2^{\circ} 27^{\prime} \mathrm{W}\right)$, Villar del Horno, Pajaroncillo, Cuenca province, were collected and submitted 1990 by A. Gómez-Ruiz, Granada, to date the violent destruction and abandonment of an Iron Age village.

UGRA-363. VILLAR I

Sample from depth $1.6 \mathrm{~m} ; 800-400 \mathrm{cal}$ BC.

$2475 \pm 50$

$\delta^{13} C=-25.1 \%$

Comment: This sample corresponds to a temporary abandonment of the village, in the first Iron Age; expected age was $\sim 2460 \pm 100 \mathrm{BP}$.

UGRA-367. VILLAR II

Sample from depth $1.2 \mathrm{~m} ; 60 \mathrm{cal}$ BC-cal AD 140.

$1940 \pm 50$

$\delta^{13} C=-23.5 \%$

Comment: This sample corresponds to the definitive abandonment of the village, in the second Iron Age.

\section{Los Barruecos Series}

Charcoal samples from Los Barruecos $\left(39^{\circ} 25^{\prime} \mathrm{N}, 6^{\circ} 30^{\prime} \mathrm{W}\right)$, Malpartida de Cáceres, Cáceres province, were collected and submitted 1987 by M. I. Sauceda-Pizaro, Area de Prehistoria y Arqueología, Facultad de Filosofía y Letras, Universidad de Extremadura, Cáceres, to date not only the site but also the later prehistoric sequence in the Extremadura region.

UGRA-352. № 1

Sample from depth $65 \mathrm{~cm} ; 2865-2340 \mathrm{cal} \mathrm{BC}$.

UGRA-354. $\mathbf{N}^{2} 3$

Sample from depth $1.0 \mathrm{~m} ; 2451-1890 \mathrm{cal} \mathrm{BC}$.

$$
\begin{array}{r}
4000 \pm 70 \\
\delta^{13} C=-24.5 \% 0 \\
3710 \pm 80 \\
\delta^{13} C=-24.7 \% 0
\end{array}
$$


UGRA-350. Museo de El Puerto de Santa María. IMAGEN.

$870 \pm 60$

$\delta^{13} C=-25.0 \%$

Wood sample from the Museum of the town of El Puerto de Santa María, Cádiz province, submitted 1987 by J. de Lucas-Almeida. The sample dated an image of which the original polychromy had disappeared; cal AD 1020-1270.

Comment: Expected age was $\sim 760 \mathrm{BP}$.

UGRA-349. EI Pla del Riu de les Marcetes PR

$5040 \pm 100$

$\delta^{13} C=-19.7 \%$

Bones from El Pla del Riu de les Marcetes $\left(41^{\circ} 23^{\prime} \mathrm{N}, 1^{\circ} 50^{\prime} \mathrm{E}\right)$, Manresa, Barcelona province. Sample collected and submitted 1986 by J. Castany-Llusa, Instituto de Prehistoria y Arqueología, Universidad de Barcelona, to date a Neolithic grave. Ceramics and flint objects were found in the burial.

Comment: Sample from depth $1.2 \mathrm{~m}$; expected age was $\sim 5210 \pm 250 \mathrm{BP} ; 4038-3640 \mathrm{cal}$ BC.

UGRA-351 Puerto Guetaria PG

$$
\delta^{13} C=\begin{array}{r}
900 \pm 50 \\
-27.6 \% 0
\end{array}
$$

Wood from Puerto Guetaria $\left(43^{\circ} 18^{\prime} \mathrm{N}, 2^{\circ} 12^{\prime} \mathrm{W}\right)$, Guetaria, Guipuzcoa province. Sample collected and submitted 1988 by A. M. Benito, Sociedad de Ciencias Aranzadi, Museo San Telmo, San Sebastián. The sample was in a hole in a stone three-cornered anchor submerged at the entrance of the Guetaria port.

Comment: Sample from depth $9 \mathrm{~m}$ (under the sea level); cal AD 1020-1250.

\section{Ronda City Area Series}

Samples from Ronda city area $\left(36^{\circ} 45^{\prime} \mathrm{N}, 5^{\circ} 10^{\prime} \mathrm{W}\right)$, Ronda, Málaga province, were collected from 1985 to 1989 by B. Padial, J. Castilla and P. Aguayo and submitted from 1990 to 1992 by P. Aguayo, Departamento de Prehistoria y Arqueología, Universidad de Granada, to date several periods in the city as detailed below.

UGRA-376. Ro' 89 - 7556

765-390 cal BC. Expected age was $\sim 2310 \pm 150 \mathrm{BP}$.

$2400 \pm 50$

$\delta^{13} C=-25.4 \%$

Comment: Charcoal from depth $3.2 \mathrm{~m}$, to date the use of a kiln and its pottery production.

UGRA-423. RO-89-AA-6695

cal AD 1001-1168.

$955 \pm 40$

$\delta^{13} \mathrm{C}=-25.0 \%$

Comment: Charcoal from depth 3.5-3.6 m, to date the Iberic levels of establishment from Prehistory to the present time.

UGRA-427. RO-89-AA-6695

$985 \pm 40$

cal AD 981-1159.

$\delta^{13} C=-25.0 \%$

Comment: This is a repetition of the previous sample UGRA-423, in order to confirm the result.

UGRA-424. RO-87-AA-6136

$415 \pm 45$

cal AD 1419-1628.

$\delta^{13} C=-25.0 \%$

Comment: Charcoal from depth 3.1-3.2 m, to date the same as UGRA-423. 
UGRA-425. RO-89-AA-6671

$930 \pm 40$

cal AD 1015-1213.

$\delta^{13} C=-25.0 \%$

Comment: Charcoal from depth $3.4 \mathrm{~m}$, to date the same as UGRA-423 and UGRA-425.

UGRA-426. RO-89-AA-C/7

$2495 \pm 50$

$800-410 \mathrm{cal}$ BC. Expected age was $\sim 2700 \pm 250 \mathrm{BP}$.

$\delta^{13} C=-25.0 \%$

Comment: Wheat seeds sample from depth $4.5 \mathrm{~m}$, to date Final Bronze Age levels in the site.

UGRA-432. RO-85 GC 3090

$2730 \pm 70$

$1040-800$ cal BC.

$\delta^{13} C=-25.0 \%$

Comment: Charcoal sample, to date levels of superimposed villages.

\section{Las Viñas Series}

Shell samples from Las Viñas $\left(36^{\circ} 39^{\prime} \mathrm{N}, 6^{\circ} 10^{\prime} \mathrm{W}\right)$, El Puerto de Santa María, Cádiz province, were collected and submitted 1987 by F. Giles-Pacheco, Municipal Museum of El Puerto de Santa María.

UGRA-369. Silo $\mathrm{n}^{2} 50$

$4800 \pm 90$

3350-2890 cal BC.

$\delta^{13} \mathrm{C}=+0.15 \%$

Comment: Shells from depth $1.6 \mathrm{~m}$, to date the geographic area of western Andalusia.

UGRA-370. Silo $\mathrm{n}^{2} 16$

$4950 \pm 60$

cal AD 1001-1168.

$\delta^{13} C=-1.00 \%$

Comment: Shells from depth 1.2-1.5 m. This is the first dating of the site context; it can be related to nearby Chalcolithic sites with similar pottery.

\section{PORTUGAL}

UGRA-355 Mamoa 1 de Chã de Carvalhal Amostra n² 2

$5860 \pm 60$

$\delta^{13} C=-25.7 \%$

Charcoal from Mamoa 1 de Chã de Carvalhal $\left(41^{\circ} 08^{\prime} \mathrm{N}, 8^{\circ} 05^{\prime} \mathrm{W}\right)$, Serra da Aboboreira, Baião, Distrito Porto, Douro Litoral province. Sample collected 1986 and submitted 1988 by D. de Jesus da Cruz, Instituto de Arqueologia, Faculdade de Letras, Universidade de Coimbra. The sample is from a megalithic necropolis with more than 40 tumulis. To date the Megalithic tomb episode in the region.

Comment: Sample from depth $1.29 \mathrm{~m} ; 4900-4586 \mathrm{cal} \mathrm{BC}$.

\section{GeOLOGICAL SAMPLES}

SPAIN

\section{Rambla Guzmaina Series}

Wood samples from Rambla Guzmaina $\left(37^{\circ} 24^{\prime} \mathrm{N}, 1^{\circ} 58^{\prime} \mathrm{W}\right)$, Huercal Overa, Almería province, collected 1990 by A. Martín-Penela and submitted 1990 by L. García-Rossell, Instituto Andaluz de Geología Mediterránea, Facultad de Ciencias, Universidad de Granada, to study an episode of recent sedimentation in the Almanzora River basin.

UGRA-371. G-A-I Sup.

Sample from depth $1.3 \mathrm{~m}$; cal AD 1522-1955.

$200 \pm 60$

$\delta^{13} C=-25.3 \%$ 
UGRA-372. G-A-I Inf.

Modern

Sample from depth $2.3 \mathrm{~m}$.

$\delta^{13} C=-24.9 \%$

UGRA-373. G-A-II

$>$ Modern

Sample from depth $30 \mathrm{~cm}$.

$\delta^{13} C=-25.0 \%$

\section{Palaeobotanical samples}

SPAIN

Lobeiras Series

Samples from Lobeiras $\left(43^{\circ} 25^{\prime} \mathrm{N}, 7^{\circ} 31^{\prime} \mathrm{W}\right)$, Vivero, Lugo province, collected and submitted 1989 by M. P. Saa-Otero, Colegio Universitario de Orense, Las Lagunas, Orense province, to establish the vegetation existing in this zone during the Quaternary.

UGRA-347. LOB-1

Peat sample from depth $51 \mathrm{~cm} ; 354 \mathrm{cal} \mathrm{BC-cal} \mathrm{AD} 52$.

$2080 \pm 60$

UGRA-348. LOB-2

$\delta^{13} C=-28.1 \%$

Wood sample from depth $1.2 \mathrm{~m}$.

$9800 \pm 120$

UGRA-324. Pico del Lobo. PLB II C'

$\delta^{13} C=-26.3 \%$

$1830 \pm 110$

$\delta^{13} C=-28.1 \%$

Peat from Pico del Lobo $\left(40^{\circ} 59^{\prime} \mathrm{N}, 3^{\circ} 58^{\prime} \mathrm{W}\right)$, La Pinilla, Segovia province; sample was collected and submitted 1989 by M. J. Gil-García, Departamento de Geología, Universidad de Alcalá de Henares, Madrid province, to establish the vegetation history of this zone, cal AD 670-1020.

\section{Puerto De Canencia Series}

Peat samples from Puerto de Canancia $\left(40^{\circ} 52^{\prime} \mathrm{N}, 3^{\circ} 47^{\prime} \mathrm{W}\right)$, Canencia de la Sierra, Madrid province, were collected 1988-1990 and submitted 1990 by M. J. Gil-García, Departamento de Geología, Universidad de Alcalá de Henares, Madrid province, to establish the vegetation history of this zone and confirm the pollen data.

UGRA-368. PCO

Sample from depth 80-90 cm; cal AD 714-980.

$1170 \pm 50$

UGRA-411. PCO 2

Sample from depth $1.20-1.45 \mathrm{~m}$; 900-421 cal BC.

$\delta^{13} C=-27.9 \%$

$2580 \pm 80$

$\delta^{13} C=-27.9 \%$

\section{REFERENCES}

González-Gómez, C. 1988 CALI, a computer program for calibration of radiocarbon dates. Unpublished software.

1992 University of Granada radiocarbon dates VI. Radiocarbon 34(1): 133-139.

1995 A general computer program for radiocarbon dating laboratories. In Cook, G. T., Harkness, D. D., Miller, B. F. and Scott, E. M., eds., Proceedings of the 15th International ${ }^{14} \mathrm{C}$ Conference. Radiocarbon 37(2): 789-790.

Longin, R. 1971 New method of collagen extraction for radiocarbon dating. Nature 230: 241-242.
Pearson, G. W., Pilcher, J. R., Baillie, M. G. L., Corbet, D. M. and Qua, F. 1986 High-precision ${ }^{14} \mathrm{C}$ measurements of Irish oaks to show the natural ${ }^{14} \mathrm{C}$ variations from AD 1840 to 5210 BC. In Stuiver, M. and Kra, R. S., eds., Proceedings of the 12 th International ${ }^{14} \mathrm{C}$ Conference. Radiocarbon 28(2B): 911-934.

Stuiver, M. and Polach, H. 1977 Reporting of ${ }^{14} \mathrm{C}$ data. In Stuiver, M. and Kra, R., eds., Calibration Issue. Radiocarbon 19(3): 355-363.

Stuiver, M. and Reimer, P. J. 1986 A computer program for radiocarbon age calibration. Radiocarbon 28(2B): 1022-1030. 